Article

\title{
Impediments to Sustaining South Korea's Economic Development: Pathologies of Cooperation in Intra-Team Dynamics of Technology Commercialization
}

\author{
Tahir Hameed ${ }^{1, *(\mathbb{D})}$, Peter von Staden ${ }^{2}$ and Ki-Seok Kwon ${ }^{3}(\mathbb{D}$ \\ 1 Girard School of Business, Merrimack College, North Andover, MA 01845, USA \\ 2 KEDGE Business School, 13009 Marseille, France; peter.vonstaden@kedgebs.com \\ 3 Department of Public Policy, Hanbat National University, Daejeon 34104, Korea; kiseok@hanbat.ac.kr \\ * Correspondence: hameedt@merrimack.edu
}

Received: 23 April 2019; Accepted: 23 May 2019; Published: 29 May 2019

check for updates

\begin{abstract}
Technology innovation and commercialization have been the cornerstone of South Korea's remarkable economic development. In this paper, we argue that South Korea's technology-based economic development is unsustainable without fundamental changes in its technology policy-making and implementation approaches. Developed countries' systems of innovation (SI) operating at the technology frontier have increasingly embraced bottom-up technology policy, making them more reliant on cooperation among teams at the project level. Drawing on Social Interdependence Theory, this research finds that the intra-team dynamics of South Korea's technology transfer and commercialization (TTC) process negatively impacts on not only current TTC projects, but also the transition of South Korean SI toward an integrative policy approach that fosters innovation and commercialization. It is clear that the top-down policy-making model supportive of linear models of innovation that South Korea has relied on for so long needs to be replaced. However, the current intra-team dynamics of TTC teams may continue to hinder this transition. While Korean TTC teams perceive themselves to be cooperative and effective in general, there is a pronounced lack of cathexis which undermines their cooperation. This may be an impediment to the success of technology commercialization teams and their projects. Further research is warranted to confirm this finding and explore the extent to which this problem hinders the sustained technology-led development of South Korea.
\end{abstract}

Keywords: sustainable economic development; technology commercialization; social interdependence; teamwork; cooperation; South Korea

\section{Introduction}

In the long term, the capacity of a country to achieve sustainable economic development rests on its capability to adapt its innovation system [1,2]. Continuous technology innovation and successful commercialization of cutting-edge technologies are integral components of such adaptation. South Korea is a classic case of rapid technology-based economic development [3,4]. Since the early 1950s, technology has played and continues to occupy a central role in its singular focus to reach technology frontiers. Top-down policies and implementation have been at the heart of South Korea's development [5,6]. Now, having reached the target of frontier technology development, it is imperative that the current modes of innovation as well as technology transfer and commercialization (TTC) are adapted to suit new challenges. Concerns have been raised about South Korea's poor TTC performance [7-11]. Although efforts have been made, this modal transition remains a problem [12,13]. Unless South Korea is able to find a way of implementing an appropriate and effective TTC approach, its economic development will suffer. 
As noted, top-down technology and innovation policy has been used by Asian newly industrialized economies (NIEs) as a means to drive competitiveness [5]. NIEs often implement policies that select and celebrate champions as a way of promoting competition [14]. This has led to a culture of intense competition to secure limited government resources among universities, research institutions, firms, and even teams and individuals at the project level. Traditional innovation and commercialization research has predominantly used neo-classical economic approaches to analyze policies, resources, productivity, inter-firm relationships and appropriation of technology investments in competitive settings, but they are not able to fully explain all the differences in the performance of NIEs [14,15]. In addressing this shortcoming, researchers have turned to evolutionary and institutional approaches in the study of technological capabilities, learning, knowledge accumulation and the transitions of NIEs [16,17], but even these approaches have their limitations.

A key underlying assumption of new technology innovation and commercialization policy, based on the above approaches, is that policy measures are effective by default in supporting adaptation and meeting performance goals. However, new TTC policies often fail to account for the critical role of organizations and individual human behavior in implementing these policy measures [18]. Moreover, actor level analysis of the above-noted approaches remains at higher institutional echelons, for example, at universities and research institutes. This emphasis neglects the role of an individual's beliefs and actions [19]. Therefore, it is clear that a large portion of the explanations of the failures (or variances) in innovation and TTC performance at the individual and team levels has not been accounted for. Approaches from the fields of psychology, sociology, and organizational behavior have demonstrated an important alternative perspective in explaining this missing part; see [20-24] for treatment of cognition, socio-cognition, role identity, social identity, and human capital theories in innovation and TTC domains.

There is much literature on team dynamics and cooperation that demonstrates cooperative teams perform better in attaining their goals than team members competing against each other [25-28]. However, there is little literature on how policy measures can be used to frame such desirable individual and/or team behavior-the rules and policies that govern team dynamics-in TTC teams. To this end, this research uses Social Interdependence Theory to test whether specific characteristics of TTC policy lead to higher goal interdependence between team members, which is a key source that promotes cooperation [25,29]. The three key characteristics of the policy affecting team actions and perceived goal interdependence include (1) how power is exercised within teams, (2) conflicts that arise from goal multiplicity, and (3) problems associated with group-based rewards $[10,30]$. We argue that these characteristics in the case of bottom-up policies prove to be more effective in enhancing TTC performance than top-down policies.

The analysis of the survey results of the responses provided by TTC professionals in Korean public research institutes (PRIs) demonstrates that cooperation indeed plays a key role in TTC performance. However, as will be discussed, cathexis plays a comparatively much smaller role in promoting cooperation. This may be a factor that hinders the transition of Korean SI toward better TTC performance as it approaches the technology frontier. Therefore, we conclude that to sustain technology innovation and commercialization led development, Korean SI (and the SIS of other developing nations) may find a way forward by changing its TTC policies to improve team cathexis.

The remaining sections of the paper are organized as follows: The second section provides the theoretical background and a research model and sections three and four cover the details of data collection and analysis of the research model. Section five concludes and extends the discussion on implications and further research.

\section{Theoretical Background and Research Model Development}

Technology transfer and commercialization is essentially about the outward flow of advanced technological knowledge from universities and research institutes towards users for product and systems development. Technology innovation policy plays a key role in managing national and 
industry-wide capabilities for development, identification, protection and the transfer of such knowledge [18]. Where catching-up nations typically adopt top-down innovation policy approach since it emphasizes adherence to directives [31,32], which is suitable for linear models of innovation, moving to the technology frontier requires independent thought processes and innovation at team level, which is better supported by non-linear models of innovation [10]. Increased interaction and cooperation, whether among teams, inside organizations (universities or research institutes) or across regional boundaries, stimulates improvements in innovation and technology transfer [32]. Therefore, the focus here is on studying factors that promote cooperation (or competition) in TTC teams.

In his seminal work on cooperation, Deutsch [29] underscores that structure, goals and effective team dynamics are causally interlinked. Over time, his ideas have evolved into what is known as Social Interdependence Theory (for evolution see [25]). This paper draws on this theory to frame the impact of team member behavior on TTC project performance. The second strand of this research is anchored in exploring the policy characteristics and structure underlying TTC teamwork and performance of South Korea. The research model examines the relationships between management actions (structures) guiding team work on TTC projects, perceived social interdependence among team members, cooperative behavior of the team, team effectiveness and, ultimately, the performance of TTC projects.

\subsection{Social Interdependence Theory}

At the turn of the 20th century, research on cooperation received early inspiration from developments in physics and the then emerging school of Gestalt Psychology. Since then, Social Interdependence Theory has established causal links between team dynamics and performance. In particular, it shows that goal structure within and between teams has a direct impact on how team members view the behavior of collaborators and, in turn, how members will act. When team members believe that goal structures and consequent goal directed behavior of fellow members is contrary to personal goals, negative interdependence could develop. If so, individuals would pursue personal goals that send similar signals to fellow members-non-cooperative goal directed behavior-and so undermine overall team cooperation. Conversely, when goal structures lead to positive interdependence, individual goal pursuit affords benefits to the individual and the team. In the main, cooperation and positive interdependence leads to superior team performance. Deutsch identifies cathexis, substitutability and inducibility as the three key psychological processes that derive from the dynamic of the interaction between actors. The dynamic is considered "effective" when it "improves the person's chances of obtaining a goal" [25] p. 289. Conversely, when goal structures lead to negative interdependence, that is to say, when an individual believes that the actions of others are contrary to his or her own best interests, the effectiveness of the team will suffer, to wit, the organization is "bungling" (Ibid.).

\subsubsection{Cathexis}

The psychological energy that individuals invest in others-cathexis-is essential to creating a cooperative working environment. By extension, the more team members positively cathect, the tighter the resulting bonds are that engender cooperation. Importantly, cathexis shapes attitudes. So, individuals (and at the collective level, organizations) that, aggregately speaking, have positive cathexis, are better disposed to respond to environmental challenges. On this basis, in cooperative environments "effective actions are cathected positively and bungling actions are cathected negatively" [25,29].

\subsubsection{Substitutability}

Tensions arise among team members in pursuit of goals and the release of this tension is important for the team. For example, it is common that in an organizational setting, individuals, once assigned particular goals, are required to interrupt work and to direct their efforts elsewhere. Evidence shows that as long as the original task is not completed, he or she who was originally assigned the task will harbor feelings of frustration and tension until the task is completed [25]. This reduces tension, 
engenders positive cathexis and brings the team closer to realizing its goals. Substitutability is thus an important mechanism by which inevitable tensions may be alleviated and reinforce the cooperativeness of the group.

\subsubsection{Inducibility}

Where the diffusion of tension within groups is important to foster positive interdependence and advance cooperation, the openness of team members to each other-inducibility-serves to create psychological accessibility and in so doing provides normative control [25]. The greater the inducibility, the more likely that the word and deed of team members would result in others engaging in promotive goal activity. Team members are more cooperative than competitive (or individualistic) under situations of mutual influence $[29,33,34]$. In competitive environments, there is a tendency to obstruct or render ineffective the actions of others leading to team "bungling". This is in contrast to situations of cooperation where actors "overwhelmingly tend to be supportive rather than coercive" [25].

In sum, the three psychological processes of cathexis, substitutability and inducibility shape how team members interact. Where contrient patterns of behavior take hold, their interpersonal relationships would suffer. Figure 1 shows these psychological processes in diagrammatic form:

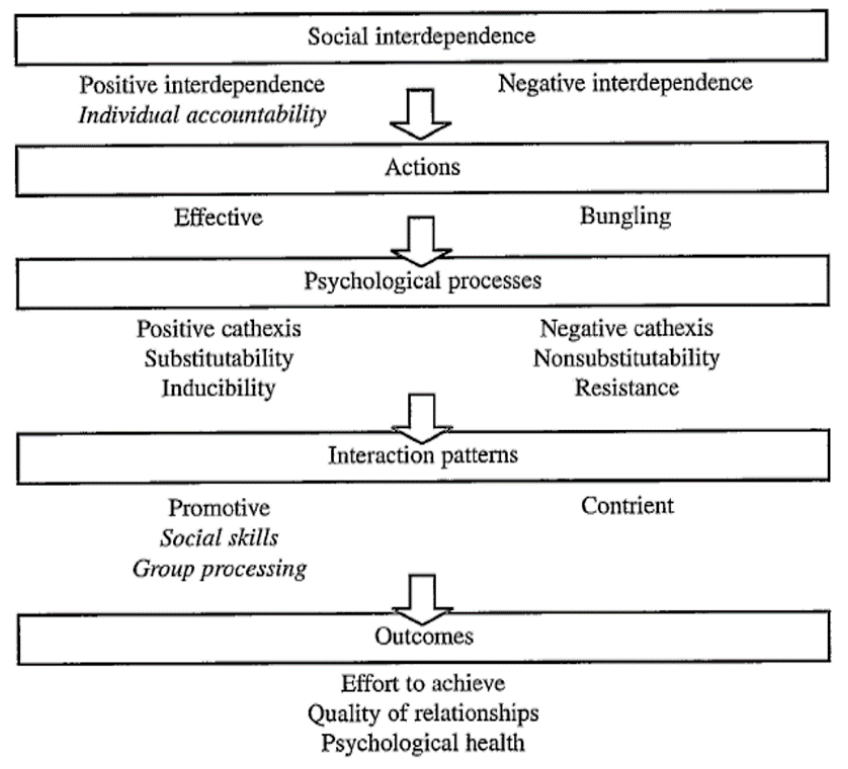

Figure 1. Social Interdependence Theory explained; adapted from [25].

\subsection{Issues of Top-Down Approaches in Technology Commercialization Teams}

Previous research on South Korea's TTC policy and process highlights several issues of top-down policies including the dominant role of public research institutions over private partners, the dominance of conglomerate research and development (R\&D) organizations in benefiting from public R \& D more than SMEs, top-down project allocations, low (inappropriate) budget allocations, low monitoring, low job satisfaction rates and high turnovers of TTC staffers [35-37]. Qualitative research focused on inner details of the TTC professionals work has also highlighted three prominent issues with Korean TTC policy and process: (1) The role of government and powerful officials wielding influence over strategic and operational decisions; (2) the perceived level of conflicts that arise from goal multiplicity; and (3) problems associated with fairness of group-based rewards policies and their distribution [10]. These three problems apparently are key to the perceptions of teams, their missions (projects) and their interdependence on each other for success of their projects. The following sub-sections discuss these three elements at some length, following which, a research model has been developed to examine their inter-relationships with perceived social interdependence, cooperative teamwork, and perceived performance of TTC project teams. 


\subsubsection{Power Influence}

As indicated in the previous sections, there are two major approaches to strategic decision-making and work distribution in innovation teams, that is, top-down and bottom-up [38]. These two opposing approaches are also associated with coercive and promotive power influence [30]. Tjosvold, Andrews and Struthers [30] demonstrated that coercive power influence by managers does not always lead to a team's full acceptance of the decision in question. In fact, evidence shows that teams tend to resist what they consider as standardized (or institutional) solutions enforced by the top when in disregard of the conditions on the ground $[39,40]$. Team members, based on their professional experiences from everyday work, consider themselves competent enough to judge the best course of action and therefore often show "cynical resistance" or, as expressed in terms of Social Interdependence Theory, "bungling".

Hameed, von Staden and Kwon [10] noted that, in the South Korean TTC context, interviewees frequently voiced concerns about TTC top-down policy design as well as top-down operational decision-making. Consequently, team members facing top-down (or coercive) power-influence develop less receptive attitudes towards their managers' goals underscoring the disjuncture between top management and themselves [29]. This leads to their lower inducibility. Conversely, a leadership approach that exercises power influence in a participatory manner would promote a sense of the commonality of goals. This translates into a higher level of inducibility among team members and better cooperation. Therefore, it can be hypothesized:

Hypothesis 1 (H1). Coercive power influence leads to resistance (lack of inducibility) among members of a team, whereas promotive power influence leads to inducibility.

\subsubsection{Goal Multiplicity}

Commercialization of public R \& D is quite complex, involving scientists, engineers, intermediaries, technology managers, and business owners constantly under the oversight of government officers. Much organizational literature has stressed that ambiguity, diversity and multiplicity of goals in public organizations negatively affect the attitudes, actions and performance of team members working on public sector projects [41-43]. In particular, Lipsky highlighted the pervasiveness of the multiplicity of goals in public services. Some scholars also noted conflicts where team members were caught between the supervisors' views of the tasks and those of the other team members, hence the multiplicity. Many organizational scholars have emphasized the negative role of complex and multiple goal setting as well as individual goal prioritization over the team's goals as an explanatory factor for the weaker performance of teams and projects $[44,45]$.

Perceived multiplicity of goals may also come from the existence of widely different personal goals of team members. Five broad categories of goals conspicuous in the TTC area include technology development goals (mainly technology problem selection and solution), learning and career goals (e.g., collaborations for knowledge acquisition, securing resources), social goals (e.g., recognition, identity confirmation), monetary goals (e.g., cash rewards/bonuses, licensing fees), and performance goals (e.g., completion of assigned tasks, quality of the work). These goals can be set at individual or team levels.

Perceived goal conflict can be defined as the degree to which individuals feel that performance expectations (i.e., goals) with respect to the multiple dimensions of a task, or among multiple tasks, are incompatible $[46,47]$. This occurs when the achievement of one goal is seen by an individual as interfering with the achievement of other goal(s) [48]. Organizational scholars argue that higher levels of conflict negatively affect the attitude and behavior of employees (team members) $[49,50]$. We thus hypothesize the following with respect to the psychological processes underlying Social Interdependence Theory:

Hypothesis 2a (H2a). High goal multiplicity in teams lead to non-substitutability whereas low goal multiplicity leads to substitutability. 
Hypothesis $\mathbf{2 b} \mathbf{b} \mathbf{H} \mathbf{2 b})$. High goal multiplicity in teams lead to resistance whereas low goal multiplicity lead to inducibility.

\subsubsection{Group-Based Rewards}

Hameed, von Staden and Kwon [10] found that group reward policies and reward distribution were an important factor on the minds of South Korean TTC professionals. Most of their interviewees in Korean TTC organizations agreed that there were enough large rewards set for technology commercialization, yet they had strong opinions about how individual efforts and contributions were assessed and the corresponding distribution of rewards.

DeMatteo et al. [51] noted that the size, frequency of distribution, and allocation methods of rewards are important building blocks of the team members' perceptions about reward structures. They also found that the perceived fairness of rewards is based on the perceptions of equality and equity of invested efforts and the rewards received. In studying the cooperative behavior of salespersons, Yilmaz and Hunt [52] highlighted the differences in cooperative behavior coming from the nature of rewards, that is, financial or non-financial rewards. Other scholars have also noted the importance of distributive justice and effort-reward fairness in building an individual's perceptions [53-55].

It is, thus, that group-based reward structures play a key part in all of the three psychological processes highlighted in Social Interdependence Theory. Such group reward perceptions would not only build a willingness to push forward the team's agenda even if some team members are not able to fully contribute (substitutability), but may also bring the team together (cathexis) as well as increase their willingness to listen and influence each other (inducibility), which leads us to set out the following hypotheses:

Hypothesis 3a (H3a). Positive perceptions of group-based rewards promote substitutability, whereas negative perceptions of group-based rewards promote non-substitutability.

Hypothesis $3 \mathbf{b}(\mathbf{H} 3 \mathbf{b})$. Positive perceptions of group-based rewards promote positive cathexis, whereas negative perceptions of group-based rewards promote negative cathexis.

Hypothesis 3c (H3c). Positive perceptions of group-based rewards promote inducibility, whereas negative perceptions of group-based rewards promote resistance.

\subsection{Cooperation and Team Project Performance}

Tjosvold [56,57] demonstrated that constructive conflict management could promote discussion, improved receptivity of different ideas, and the willingness to work together, all of which lead to the improved productivity of organizations. Tauer and Harackiewicz [58] also illustrated the positive role of cooperative goal structures on an individual's motivation levels and team performance. Wageman's [59] study confirmed that group outputs are negatively affected by hybrid structures for team and individual rewards, which we see as promoting goal ambiguity among team members and their perceptions of their goal interdependence; he also noted that purely individual and purely team efforts/rewards also resulted in better team performance.

Combining this literature with the three socio-psychological processes [29] discussed previously, that is, substitutability, cathexis and inducibility, we set out the following hypotheses:

Hypothesis 4 (H4). Substitutability associates positively with cooperation between team members, whereas non-substitutability associates negatively with cooperation.

Hypothesis 5 (H5). Positive cathexis associates positively with cooperation between team members, whereas negative cathexis associates negatively with cooperation. 
Hypothesis 6 (H6). Inducibility associates positively with cooperation between team members, whereas resistance associates negatively with cooperation.

As noted earlier, the perception of interdependent goals is more likely to promote cooperative interaction among team members hence engendering cooperative behavior [56]. A comprehensive review [25] shows the positive effects of cooperative goal structures on several different sets of skills such as motor, cognitive and even special skills for technical jobs. Conversely, the role of competition has been highlighted for having a role in demotivating team members, hence adversely affecting an organization's performance [60]. We use a proxy measure for team perceptions about their effectiveness and successful project performance of the team (ProjPerf). The following hypothesis covers the inter-relationship between cooperation and team project performance.

Hypothesis 7 (H7). Cooperation among team members associates positively with team project performance, whereas competition (lack of cooperation) associates negatively with team project performance.

\subsection{Research Model}

The full research model is shown in Figure 2. The constructs of this model have been broadly classified into four groups, namely, Perceived Social Interdependence and Team Actions, Socio-psychological Processes, Perceived Effectiveness of Team Interactions, and the resulting Perceived Project (or task) Performance.

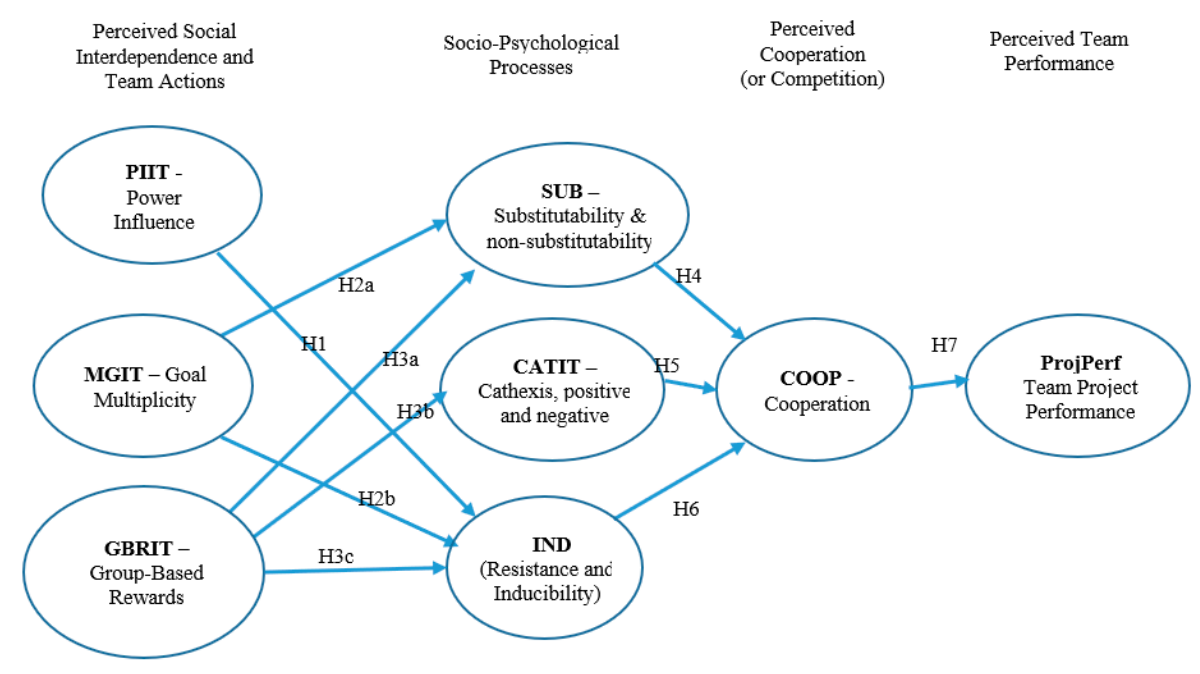

Figure 2. Proposed Research Model. Note: Since most of the constructs represent a continuum, for simplicity only one has been written in the model. For example, substitutability (SUB) represents both substitutability and non-substitutability at two ends of the Likert scale, and so on.

\section{Research Methods and Data Collection}

\subsection{Methods and Measurments}

A field survey was conducted to examine the validity of hypotheses grounded in Social Interdependence Theory. The survey instrument was based on adapted items (questions) for each construct from well-established literature and some questions developed by us. All items were answered using a seven-point Likert scale, where number 7 indicates the highest magnitude of the variable (typically perception) and 1 the lowest level, while 4 indicates a neutral value or no opinion. A few reverse-coded $(R)$ variables were also inserted to address instrument biases and ensure construct validity. To this end, each item was tested for internal validity, which is discussed later in the section on the testing of the measurement model. 
Appendix A contains all the survey items included for data collection. However, some important references and methods for development of survey are mentioned below. In order to measure two types of power influence, that is, directive influence (coercive influence) and participative influence [30], items from organizational conflict inventory [61] have been used or modified. In order to measure goal multiplicity, we have developed our own questions based on other survey items from $[49,62]$. Group-based rewards measurements are mainly focused on the notion of effort/reward fairness [54] and reward characteristics such as size and frequency to gauge if respondents feel that the levels of the rewards are appropriates [51].

The second set of constructs focusing on an individual's socio-psychological processes in team settings proposed by Social Interdependence Theory are substitutability (SUB), cathexis (CAT) and inducibility (IND). Substitutability is mainly the extent to which work of one team member can be substituted by another team member to maximize team achievement. Expertise among team members increases the possibility of substitutability and vice versa [63]. A higher frequency of interactions increases the possibility to obstruct others' task performance [64]. Also, if team members perceive their team goals are not much interdependent, higher task interdependence might negatively affect cooperative behavior and substitutability [65]. Cathexis has also been measured, which is similar to affection in team contexts. Interpersonal attraction is very important in teams for social identification and psychological group formation [66]. Keeping the above in mind, a few items were adapted from the Carron et al. [67] questionnaire on cohesion in sport teams, and a few others were developed for this study.

Cooperation was measured by eight items on discretionary role behavior and extra-role behavior, adapted from [68], who have discussed identity and other engagement issues in relation to team cooperative behavior. Lastly, we referred to the Team Diagnostic Survey by Wageman et al. [69] and developed our own items to measure the overall perception of team performance on their projects. Please refer to Appendix A for all the survey items used in measuring the constructs set in research model.

\subsection{Data Collection}

The survey was distributed to more than 200 South Korean professionals involved in TTC projects either in PRIs, Technology Licensing Organizations (TLOs), or government offices monitoring these projects and interacting with the first two groups. A total of around 150 responses were returned, of which only 115 were deemed suitable for inclusion in the analysis after deletions and cleaning based on correctness and completeness of the responses. The sample size of 115 is adequate to test the research model which is more than the 100 advanced by [70].

Table 1 presents basic characteristics of the sample. All participants are South Korean nationals mostly working within PRIs and TLOs.

Table 1. Survey sample characteristics.

\begin{tabular}{ccc}
\hline & Category & Count \\
\hline \multirow{2}{*}{ Gender } & Male & 96 \\
& Female & 19 \\
\hline \multirow{3}{*}{ Education } & Bachelor & 23 \\
& Master & 37 \\
& Doctorate & 51 \\
& Others/Not Mentioned & 4 \\
\hline \multirow{2}{*}{ Profession/Role } & Tech. Transfer Professional & 38 \\
& Scientist or Engineer & 55 \\
& Business Manager/Owner & 17 \\
& Ministry or Gov. Official & 1 \\
& Not mentioned & 4 \\
\hline
\end{tabular}




\section{Model Testing, Analysis and Findings}

\subsection{Assessment of the Measurement Model}

The proposed model and hypotheses were tested using the structural equation modeling (SEM) partial least squares (PLS) method, since it enables testing of the psychometric properties of each measurement scale (measurement model) as well as the strength and direction of relationships between constructs (structural model). PLS is particularly suitable for exploratory research and early stage theory development, since it allows for the modelling of latent variables even with small-to-medium samples [71]. We used SmartPLS version 3 software [72].

Table 2 shows the assessment of the measurement model. Internal consistency reliability was investigated by using Cronbach's alpha [73]. The constructs in the proposed model are above the 0.7 threshold, indicating a high reliability of items used for each construct. This also includes both adapted and newly developed items. As an additional measure, composite reliability indicators for all constructs being above 0.7 also indicates high reliability of the scaled items used for each construct.

Table 2. Internal consistency of the measurement model.

\begin{tabular}{cccc}
\hline & Cronbach's Alpha & $\begin{array}{c}\text { Average Variance } \\
\text { Extracted (AVE) }\end{array}$ & Composite Reliability \\
\hline CATIT (Cathexis Intra-Team) & 0.778 & 0.663 & 0.853 \\
COOP (Cooperative Behavior) & 0.935 & 0.692 & 0.947 \\
GBRIT (Group Based Rewards) & 0.902 & 0.835 & 0.938 \\
IND (Inducibility) & 0.766 & 0.686 & 0.867 \\
MGIT (Multiplicity of Goals) & 0.743 & 0.662 & 0.854 \\
PIIT (Power Influence) & 0.851 & 0.762 & 0.905 \\
ProjPerf (Project Performance) & 0.881 & 0.680 & 0.913 \\
SUB (Substitutability) & 0.747 & 0.664 & 0.854 \\
\hline
\end{tabular}

Convergent validity and discriminant validity were assessed through Fornell-Larcker criterion measures. The average variance extracted (AVE) for the measures indicate high convergent validity since it was above the threshold value of 0.5 . Discriminant validity was assessed using the square root of AVE which, for each construct, was greater than the correlations between itself and all other constructs-see Table 3. All the constructs are more strongly correlated to their own measures than those of others, hence confirming discriminant validity. The measurements demonstrate high strength of the measurement model including its constructs and the scale items.

Table 3. Convergent validity and discriminant validity-Fornell-Larcker Criterion.

\begin{tabular}{ccccccccc}
\hline & CATIT & COOP & GBRIT & IND & MGIT & PIIT & ProjPer & SUB \\
\hline CATIT & $\mathbf{0 . 8 1 4}$ & & & & & & & \\
COOP & -0.057 & $\mathbf{0 . 8 3 2}$ & & & & & & \\
GBRIT & 0.163 & 0.179 & $\mathbf{0 . 9 1 4}$ & & & & & \\
IND & -0.202 & 0.572 & 0.324 & $\mathbf{0 . 8 2 8}$ & & & & \\
MGIT & -0.138 & 0.670 & 0.211 & 0.606 & $\mathbf{0 . 8 1 3}$ & & & \\
PIIT & 0.140 & 0.101 & 0.427 & 0.251 & 0.101 & $\mathbf{0 . 8 7 3}$ & & \\
ProjPer & -0.146 & 0.431 & 0.312 & 0.677 & 0.488 & 0.279 & $\mathbf{0 . 8 2 4}$ & \\
SUB & -0.021 & 0.558 & 0.016 & 0.496 & 0.499 & -0.016 & 0.466 & $\mathbf{0 . 8 1 5}$ \\
\hline
\end{tabular}

Note: Bold numbers represent square root of AVE value of the correlation between constructs themselves.

\subsection{Testing the Structural Model}

To validate the research model, the overall explanatory power of the structural model, the variance, and the magnitude and strength of the paths (inter-relationships) were assessed. Figure 3 presents the results obtained from the PLS analysis of the proposed research model. The coefficient of determination (i.e., R2) is 0.428 for Perceived Cooperation and 0.190 for Team Project Performance. This means the 
structural model explains about $43 \%$ of the variance in Perceived Cooperation and about $19 \%$ of the variance in Perceived Project Performance, respectively. The model fit statistic, SRMR (Standardized Root Mean Square Residual), is 0.08 , which is acceptable at the threshold level of good fit. Considering this study is among the first in the context of innovation and technology commercialization, the model provides good explanatory power of Social Interdependence Theory in a poorly understood area.

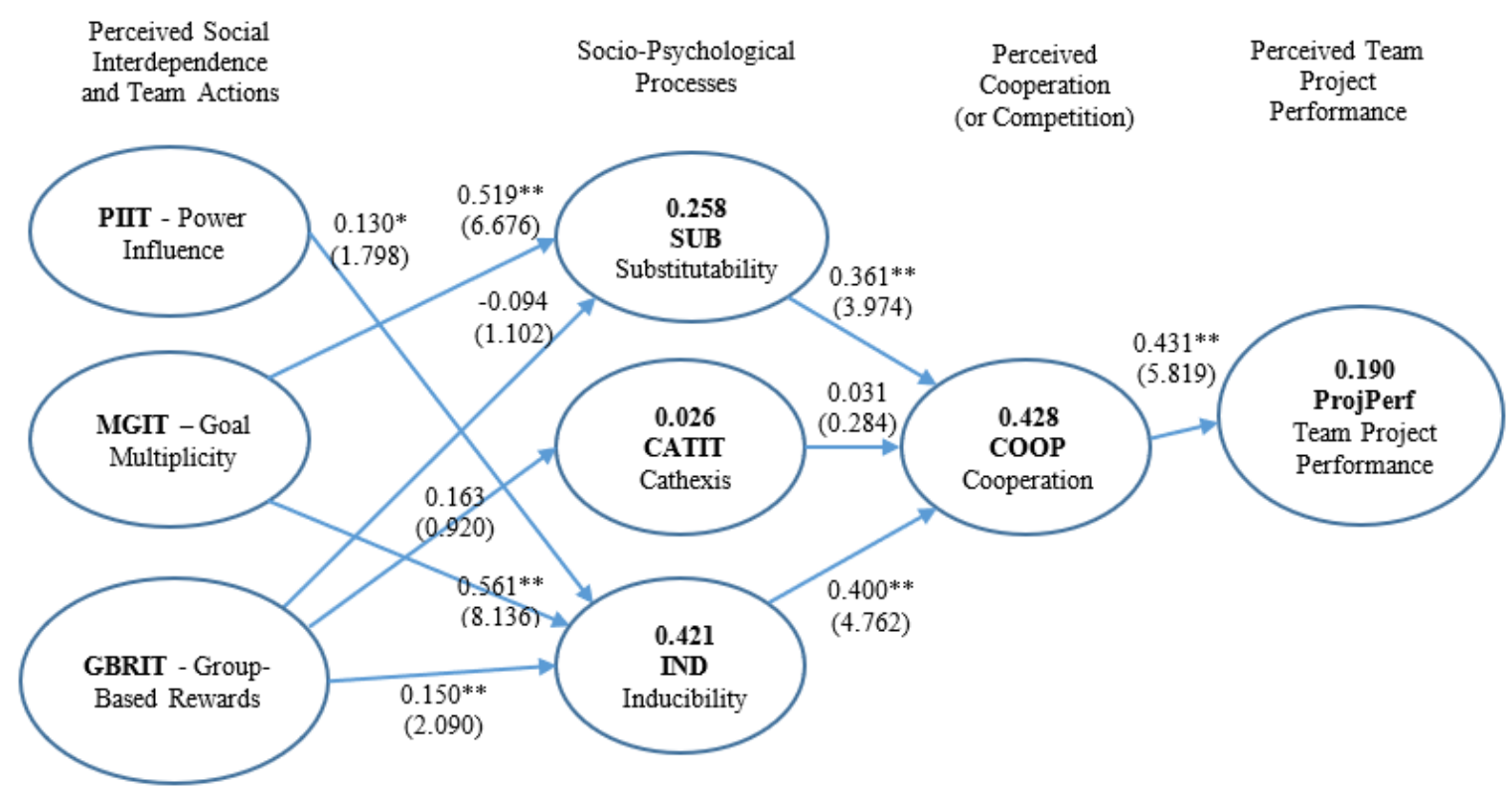

Figure 3. Results of structural model with path coefficients (associated t-statistics are in parentheses). ${ }^{*} p<0.1,{ }^{* *} p<0.05$. Values inside the constructs (ovals) represent $\mathrm{R}^{2}$.

Correspondingly, the results indicate that team project performance and cooperation among members of a TTC team are positively related (statistically significant up to the 0.5 level) with two of the three constructs of Social Interdependence Theory, that is, substitutability and inducibility. However, one of the major constructs of the Social Interdependence Theory, namely, cathexis, is not related at all to the perceived level of cooperation among TTC team members in South Korean PRIs.

Power influence appears to be significantly related to inducibility, as proposed in the research model, though at the lesser significance level of 0.10. This means that TTC teams in Korea conform to the theoretical notion that coercive power influence reduces the willingness of team members to listen and accommodate other team members' viewpoints, while exertion of participatory power influence enhances one's willingness to listen to and accommodate others. That implies top-down decision-making and stringent hierarchical organizational control negatively affects cooperation among team members and vice versa.

Goal multiplicity is significantly related to both substitutability and inducibility. In the former, it confirms that Korean TTC teams perceive that if one's team members have to deal with multiple goals (which most members in any typical organization do have to) there is a higher likelihood that other team members are aware of the need to substitute and do not think their common goals are deeply affected. In the case of positive relations between goal multiplicity and inducibility, it implies that the existence of multiple goals is understood and acceptable to team members as they are willing to listen and accommodate each other's viewpoints and work in such situations [74]. It is surprising that Korean TTC team members neither indicate positive feeling towards each other (cathexis), nor do they appear to realize and be willing to substitute for others' work. Such perception and resulting behavior warrant further investigation and discussion. Table 4 provides a complete summary of the hypotheses, supported or otherwise. 
Table 4. Results of hypothesis testing.

\begin{tabular}{ccc}
\hline Paths & Hypothesis & Result \\
\hline Power Influence $>$ Resistance & $\mathrm{H} 1$ & Supported \\
Goal Multiplicity $>$ Non-Substitutability & $\mathrm{H} 2 \mathrm{~b}$ & Supported \\
Goal Multiplicity $>$ Resistance & $\mathrm{H} 2 \mathrm{~b}$ & Supported \\
Group Based Rewards $>$ Substitutability & $\mathrm{H} 3 \mathrm{a}$ & Not Supported \\
Group Based Rewards $>$ Positive Cathexis & $\mathrm{H} 3 \mathrm{~b}$ & Not Supported \\
Group Based Rewards > Inducibility & $\mathrm{H} 3 \mathrm{c}$ & Supported \\
Substitutability $>$ Cooperation & $\mathrm{H} 4$ & Supported \\
Positive Cathexis $>$ Cooperation & $\mathrm{H} 5$ & Not Supported \\
Inducibility $>$ Cooperation & $\mathrm{H} 6$ & Supported \\
Cooperation $>$ Team Project Performance & $\mathrm{H} 7$ & Supported \\
\hline
\end{tabular}

\section{Conclusions and Discussion}

\subsection{Findings}

A structured path analysis of the data collected from South Korean TTC teams against the research model developed for this study has, to a large degree, confirmed the hypotheses, but has also raised some issues. The first significant finding is that the consistency of the positive relationship between perceived cooperation and team performance corresponds to the theoretical assertions of Social Interdependence Theory (See Hypotheses 7).

Secondly, the more important findings pertain to the tested relationships between team actions and the socio-psychological processes of TTC team members. It has been found that all three constructs, namely, participative power influence, goal multiplicity and group-based rewards, positively affect inducibility among team members. Similarly, we note goal multiplicity positively promoted substitutability among team members. Also, the abundance and fairness of group-based reward structures positively supported inducibility. Top-down policy approach driven team actions, such as coercive power influence, high goal multiplicity and absence of group rewards or their unfair distribution, affects cooperation negatively. Participative power influence and lower goal multiplicity group-based rewards, on the other hand, positively affect cooperation among teams. In sum, these findings affirm the general validity of most of the proposed hypotheses about social interdependence and team actions within the context of top-down policy-driven regulation of team behavior.

However, it is interesting that, while the relationship between goal multiplicity and substitutability is supported, the relationship between group-based rewards and substitutability is not. One explanation may be found in Johnson and Johnson's [25] observation that under certain circumstances substitutability may lead to functional specialization. If resources are scarce, for example, co-operators may decide to employ a strategy of protecting their own interests, thereby reducing substitutability. Given the technical nature of TTC and the competitive environment fostered by South Korea's top down approach, this may be the case. If functional specialization has developed, team members' disposition to goal multiplicity would not be affected but an individual's perception of what is a fair reward given their specialization may engender a sense of unfairness and so undermine cooperation. In other words, functional specialization and rewards need to be aligned. An alternative explanation may be found in the expressed discontent over the fact that rewards are determined by government officials and, as seen by them, unfairly allocated [10].

The third finding turned out to be most notable during the testing of this model. While substitutability and inducibility promotes cooperation among Korean team members, cathexis does not appear to have any role in building cooperation among Korean TTC teams. Team members do not invest much, or perhaps, no mental or emotional energy (cathect) with others in their teams. This lack of cathexis warrants further discussion as well as further research, since it might be a major cause behind the poor performance of Korean TTC projects. 
In light of the knowledge that team members in the main are willing to work cooperatively (substitutability) and to listen to each other (inducibility), but not invest energy in each other, suggests that while outwardly cooperative, they retain emotional and/or mental reluctance to bond. In short, South Korean TTC members are capable of setting aside whatever emotional misgivings or hesitations they may feel for others and get on with their job of being a team player. This lends credence to our initial observation that team members perceive that they are cooperative and effective. One may postulate that the collectivist nature of South Korean society embedded in their education system and carried forward into the work place makes for good team players, yet, all the while, not necessarily liking each other.

This duality is observed by Johnson and Johnson [25] in their discussion on the pathologies of cooperation. As a general observation, cooperation, they argue, is fragile: There is an inherent desire to compete in the group context which, if left unchecked, may rise and undermine whatever cooperative dynamic has been created. In other words, it cannot be taken for granted that just because people seem to work together that there may not be something deeper amiss. In our specific case, where substitutability (mostly) and inducibility are supported and cathexis (not in either relationship) echoes the sentiments of Korean TTC professionals noted in previous research [10] and draws into relief the potential importance of this. Johnson and Johnson [25] point out that as "cliques develop, in-group favoritism grows, and nepotism increases, there is a lessening of group effectiveness and a weakening of overall group cohesion" (p. 297). On the basis of this research's results, does the case of South Korea's TTC team dynamics confirm (or reject) this view? The phenomenon of in-group versus out-group is well documented in the literature $[68,75,76]$; however, in the main, this literature relies on studies performed on non-Asian and specifically non-South Korean respondents.

A further interpretation on the variable of cathexis may be found in the cultural anthropology literature on Korean's and their interpersonal relationships. Hur [77] asserts that the identity of Koreans tends to be defined in terms of their relationship with others rather than independent reflection on themselves. Therefore, they are more dependent on those with whom they have contact rather than society at large or institutions. Kim [78] argues that trust among Koreans has steadily declined during the last 30 years and is low in comparison to other developed countries. Similarly, Kwon [79] maintains that Koreans are particularly concerned about group exclusion. Thus, from the Korean perspective, cooperation and sensitivity to the group is a compensatory measure given low cathexis.

The overall findings, therefore, confirm that cooperation within TTC teams has a role in explaining the sub-optimal technology commercialization performance of South Korea. These confirmations and negations of inter-relationships noted above suggest that the dynamic of South Korean TTC is problematic, and draws into question the sustainability of South Korea's technology-driven economic development as it moves toward the technology frontier [80]. However, before turning to a discussion on theoretical and policy implications in the next subsection, it is important to stress at this point that this research based on a sociological perspective has identified a problem with Korean TTC and the necessity for change in its related policies. Unlike traditional approaches which support increased R\&D spending and control in the initial stages of catch-up, we anticipate that there would be diminishing returns from R\&D investments in transition stages unless the people and their actions when working in teams are accounted for. We advance that this interpretation has received scant attention in the literature. Furthermore, this contribution is framed by Social Interdependence Theory-a theory that has never been used in the analysis of South Korea's TTC. Importantly, this theory distinguishes itself from the few studies that use sociological approaches, such as Bandura's Social Identity Theory (STI), which focusses on actor behavior and perception. In the case of STI, the analytical lens is on the relationship between actors as a function of the structure in which it is located. As implications of this will be shortly discussed, Social Interdependence Theory affords greater practical analytical purchase.

Further, by adopting a sociological approach, in particular Social Interdependence Theory, it has afforded us a theoretical lens to conceptualize TTC as more than just a process of handing off innovation from one actor to the next. To be sure, such is the process, but actors operate within teams which are 
structured, and, in turn, influence how said actor receives and transfers technology. Our research shows that there are problems at the team level of South Korea's TTC process and they are impediments to the modal change necessary to successfully compete at the technology frontier. While structural in nature, that is to say, the rules that frame and motivate team members, are a source of the problem is at the very heart of the process namely the dynamic of the team itself.

\subsection{Implications and Further Research}

South Korean TTC inter-team dynamics work well enough under top-down policy direction for technological catch-up. The remarkable growth argues that whatever problems may exist within TTC teams, the drag was manifestly overcome by sustained high-levels of government investment and disciplined workers. But, the real question — and that which is at the nub of this research-is how that "drag" will play out as South Korea competes at the technology frontier. Korean policy makers have to answer that question.

As discussed, linearity needs to give way to independence to allow teams to be innovative. Our findings suggest that this may be a problem. According to Social Interdependence Theory, cooperation is normally superior to competition in achieving selected goals, since TTC members see themselves to be cooperative but not willing to create a cohesive group. Under strong directorial guidance from the top, in-group behavior may be mitigated by both institutional structural control and the collectivist and cooperative mentality fostered through education and elsewhere in society. However, in-group behavior in circumstances where the directorial reins are loosened may result in much less cooperation rather than more.

Further research as well as policy attention should be directed at the enduring trust relationships first formed in South Korea's high schools and other organizations. Participation in office activities that frequently include after work hours is a typical part of Korean work culture. Yet, despite whatever bonds this may foster, our results indicate that Korean team members seem to engage in such activities and work with each other without actually developing long lasting trust.

There are certain limitations to this research that highlight opportunities for future exploration. Our dataset is specifically from a country that is comparatively homogenous in ethnicity, work ethic and organizational culture [81]. Although Southeast Asian NIEs like Singapore, Hong Kong and Taiwan share the catch-up status and some cultural roots, the results cannot be generalized broadly to the SIs of these catching-up nations due to their socio-cultural and industry diversity. A broader dataset from multiple developing NIEs facing sustainability issues of their economic development would be needed to make such a generalization. Some team cooperation literature grounded in Social Interdependence Theory is available from Chinese and Hong Kong organizations [82], but these are business teams and not public sector teams, and are therefore different. Lastly, one more venue for future research could be exploring inter-team dynamics of TTC teams from multiple organizations working on same technology project, for instance on a big science project. In such cases, power influence, goal multiplicity and group-based rewards might depict different effects in engendering inter-team cooperation.

Author Contributions: Conceptualization, T.H. and P.v.S.; Formal analysis, T.H.; Investigation, T.H. and P.v.S.; Methodology, T.H.; Resources, K.-S.K.; Writing—original draft, T.H. and P.v.S.; Writing—review \& editing, T.H., P.v.S. and K.-S.K.

Funding: This research received no external funding.

Conflicts of Interest: The authors declare no conflict of interest. 


\section{Appendix A. Survey Questionnaire}

\begin{tabular}{|c|c|c|c|c|c|c|c|}
\hline & $\begin{array}{c}\text { (1) } \\
\text { Strongly } \\
\text { Disagree }\end{array}$ & $\begin{array}{l}\text { (2) Fairly } \\
\text { Disagree }\end{array}$ & \begin{tabular}{l}
\multicolumn{1}{c}{$(3)$} \\
Somewhat \\
Disagree
\end{tabular} & $\begin{array}{c}(4) \\
\text { Neutral }\end{array}$ & $\begin{array}{c}\text { (5) } \\
\text { Somewhat } \\
\text { Agree }\end{array}$ & $\begin{array}{c}\text { (6) } \\
\text { Fairly } \\
\text { Agree }\end{array}$ & $\begin{array}{c}(7) \\
\text { Strongly } \\
\text { Agree }\end{array}$ \\
\hline \multicolumn{8}{|c|}{ Power-Influence-Intra-Team Power-Influence of the Leader/Manager } \\
\hline \multicolumn{8}{|c|}{ My boss/manager } \\
\hline tells me what to do and how to do it & $\square$ & $\square$ & $\square$ & $\square$ & $\square$ & $\square$ & $\square$ \\
\hline gives me detailed instructions on how things should be done & $\square$ & $\square$ & $\square$ & $\square$ & $\square$ & $\square$ & $\square$ \\
\hline checks and/or criticizes my work regularly & $\square$ & $\square$ & $\square$ & $\square$ & $\square$ & $\square$ & $\square$ \\
\hline \multicolumn{8}{|c|}{ Multiplicity of Goals } \\
\hline \multicolumn{8}{|c|}{ Considering the goals of my team members and myself: } \\
\hline $\begin{array}{l}\text { As a member of my team, I know exactly what I am expected to } \\
\text { work on }\end{array}$ & $\square$ & $\square$ & $\square$ & $\square$ & $\square$ & $\square$ & $\square$ \\
\hline $\begin{array}{l}\text { I have some personal goals (learning, rewards, relationships etc.) } \\
\text { besides my team goals }\end{array}$ & $\square$ & $\square$ & $\square$ & $\square$ & $\square$ & $\square$ & $\square$ \\
\hline $\begin{array}{l}\text { When I do better on personal goals my team's goal achievement } \\
\text { improves }\end{array}$ & $\square$ & $\square$ & $\square$ & $\square$ & $\square$ & $\square$ & $\square$ \\
\hline \multicolumn{8}{|c|}{ Group-Based Rewards (Size/Frequency, Type, Allocation Methods) } \\
\hline \multicolumn{8}{|c|}{ Considering the distribution rewards for my team and myself } \\
\hline There are enough rewards for all team members & $\square$ & $\square$ & $\square$ & $\square$ & $\square$ & $\square$ & $\square$ \\
\hline My efforts are rewarded appropriately & $\square$ & $\square$ & $\square$ & $\square$ & $\square$ & $\square$ & $\square$ \\
\hline My efforts are rewarded timely & $\square$ & $\square$ & $\square$ & $\square$ & $\square$ & $\square$ & $\square$ \\
\hline \multicolumn{8}{|c|}{ Substitutability (Intra-team) } \\
\hline \multicolumn{8}{|c|}{ Considering the work behaviour (willingness/potential to substitute) of my team members (most of them) } \\
\hline I complete the assigned tasks very well & $\square$ & $\square$ & $\square$ & $\square$ & $\square$ & $\square$ & $\square$ \\
\hline I work extra for my team members to achieve our team goals & $\square$ & $\square$ & $\square$ & $\square$ & $\square$ & $\square$ & $\square$ \\
\hline $\begin{array}{l}\begin{array}{l}\text { My team project still achieves its goals even if some of us are not } \\
\text { working well }\end{array}\end{array}$ & $\square$ & $\square$ & $\square$ & $\square$ & $\square$ & $\square$ & $\square$ \\
\hline \multicolumn{8}{|c|}{ Cathexis } \\
\hline \multicolumn{8}{|c|}{ Thinking about the relationships and cohesion between your team members, respond to the following statements: } \\
\hline \multicolumn{8}{|c|}{ Considering the inter-personal interactions of my team } \\
\hline Some of my best friends are on this team & $\square$ & $\square$ & $\square$ & $\square$ & $\square$ & $\square$ & $\square$ \\
\hline For me, this team is the most important social group I belong to & $\square$ & $\square$ & $\square$ & $\square$ & $\square$ & $\square$ & $\square$ \\
\hline \multicolumn{8}{|c|}{$\begin{array}{c}\text { Inducibility-Inducibility refers to the willingness and openness to influence and be influenced by other's opinions and actions. Please answer the following } \\
\text { statements pertaining to inside team members: }\end{array}$} \\
\hline $\begin{array}{l}\text { I have frequent open discussions with my team members about } \\
\text { our work }\end{array}$ & $\square$ & $\square$ & $\square$ & $\square$ & $\square$ & $\square$ & $\square$ \\
\hline We choose the best course of action after deliberations & $\square$ & $\square$ & $\square$ & $\square$ & $\square$ & $\square$ & $\square$ \\
\hline We generally accept good proposals from the experts amongst us & $\square$ & $\square$ & $\square$ & $\square$ & $\square$ & $\square$ & $\square$ \\
\hline \multicolumn{8}{|c|}{ Cooperative Interactions/Behavior } \\
\hline I try to comply with work rules and policies & $\square$ & $\square$ & $\square$ & $\square$ & $\square$ & $\square$ & $\square$ \\
\hline $\begin{array}{l}\text { I try to implement policies and directives even when unobserved } \\
\text { by others. }\end{array}$ & $\square$ & $\square$ & $\square$ & $\square$ & $\square$ & $\square$ & $\square$ \\
\hline I fulfil my job responsibilities & $\square$ & $\square$ & $\square$ & $\square$ & $\square$ & $\square$ & $\square$ \\
\hline I complete the projects adequately & $\square$ & $\square$ & $\square$ & $\square$ & $\square$ & $\square$ & $\square$ \\
\hline I give my best at work & $\square$ & $\square$ & $\square$ & $\square$ & $\square$ & $\square$ & $\square$ \\
\hline I try to help my supervisor & $\square$ & $\square$ & $\square$ & $\square$ & $\square$ & $\square$ & $\square$ \\
\hline I put in extra effort & $\square$ & $\square$ & $\square$ & $\square$ & $\square$ & $\square$ & $\square$ \\
\hline I lend an extra hand to others & $\square$ & $\square$ & $\square$ & $\square$ & $\square$ & $\square$ & $\square$ \\
\hline \multicolumn{8}{|c|}{ Team Project Performance } \\
\hline \multicolumn{8}{|l|}{ My team } \\
\hline members are motivated to have the team succeed. & $\square$ & $\square$ & $\square$ & $\square$ & $\square$ & $\square$ & $\square$ \\
\hline $\begin{array}{l}\text { successfully achieved most of our assigned targets or meet } \\
\text { timelines (if projects are on-going) }\end{array}$ & $\square$ & $\square$ & $\square$ & $\square$ & $\square$ & $\square$ & $\square$ \\
\hline $\begin{array}{l}\text { did better than most other teams in achieving assigned targets } \\
\text { (or timelines) }\end{array}$ & $\square$ & $\square$ & $\square$ & $\square$ & $\square$ & $\square$ & $\square$ \\
\hline achievements were beyond the assigned targets & 口 & 口 & 口 & 口 & 口 & $\square$ & 口 \\
\hline $\begin{array}{l}\text { Most of our organizational projects successfully achieved their } \\
\text { targets (or timelines) }\end{array}$ & 口 & $\square$ & $\square$ & $\square$ & 口 & $\square$ & $\square$ \\
\hline
\end{tabular}




\section{References}

1. Freeman, C. Technology, Policy, and Economic Performance: Lessons from Japan; Pinter: London, UK, 1987.

2. Lundvall, B.-Å. (Ed.) National Innovation Systems: Towards a Theory of Innovation and Interactive Learning; Printer: London, UK, 1992.

3. Lee, J.; Bae, Z.-T.; Choi, D.-K. Technology development processes: A model for a developing country with a global perspective. R D Manag. 1988, 18, 235-250. [CrossRef]

4. Kim, L. Imitation to Innovation: The Dynamics of Korea's Technological Learning; Harvard Business School Press: Boston, MA, USA, 1997.

5. Vogel, E.F. The Four Little Dragons: The Spread of Industrialization in East Asia; Harvard University Press: Cambridge, MA, USA, 1991; p. 138.

6. Choung, J.-Y.; Hameed, T.; Ji, I. Catch-up in ICT standards: Policy, implementation and standards-setting in South Korea. Technol. Forecast. Soc. Chang. 2012, 79, 771-788. [CrossRef]

7. Kim, Y.; Lee, B.; Lim, Y. A comparative study of managerial features between public and private R\&D organizations in Korea: Managerial and policy implications for public R\&D organizations. Int. J. Technol. Manag. 1999, 17, 281-311.

8. Lee, Y.J.; Kim, S.U. Promoting Technology Commercialization of Universities and Government-Funded Research Institutes; Science and Technology Policy Institute: Seoul, Korea, 2013; p. 52.

9. Van Noorden, R. South Korea stretches lead in research investment. Nature 2016. [CrossRef]

10. Hameed, T.; von Staden, P.; Kwon, K.-S. Sustainable economic growth and the adaptability of a national system of innovation: A socio-cognitive explanation for South Korea's mired technology transfer and commercialization process. Sustainability 2018, 10, 1397. [CrossRef]

11. Baek, Y.; Jones, R.S. Sustaining High Growth through Innovation; OECD: Paris, France, 2005; p. 52.

12. Choung, J.-Y. Transition: From Catch-Up to Post Catch-Up. Asian J. Tech. Innov. 2016, 24 (Suppl. 1), 1-7. [CrossRef]

13. Rock, M.L.; Schumacker, R.E.; Gregg, M.; Howard, P.W.; Gable, R.A.; Zigmond, N. How Are They Now? Longer Term Effects of eCoaching through Online Bug-in-Ear Technology. Teach. Educ. Spec. Educ. 2014, 37, 161-181. [CrossRef]

14. Lall, S. Technological change and industrialization in the Asian newly industrializing economies: Achievements and challenges. In Technology, Learning and Innovation: Experiences of Newly Industrializing Countries; Kim, L., Nelson, R., Eds.; Cambridge University Press: Cambridge, MA, USA, 2000.

15. Bell, M.; Pavitt, K. Technological Accumulation and Industrial Growth: Contrasts between Developed and Developing Countries. Ind. Corp. Chang. 1993, 2, 157-210. [CrossRef]

16. Nelson, R.R. The Co-evolution of Technology, Industrial Structure, and Supporting Institutions. Ind. Corp. Chang. 1994, 3, 47-63. [CrossRef]

17. Edquist, C. Systems of Innovation: Technologies, Institutions and Organizations; Routledge: London, UK, 2013.

18. Bozeman, B. Technology transfer and public policy: A review of research and theory. Res. Policy 2000, 29, 627-655. [CrossRef]

19. Tello, S.; Latham, S.; Kijewski, V. Individual choice or institutional practice: Which guides the technology transfer decision-making process? Manag. Decis. 2010, 48, 1261-1281. [CrossRef]

20. Sund, K.J.; Galavan, R.J.; Brusoni, S. Cognition and Innovation; Emerald Publishing Limited: Bingley, UK, 2018.

21. Hoegl, M.; Gemuenden, H.G. Teamwork quality and the success of innovative projects: A theoretical concept and empirical evidence. Organ. Sci. 2001, 12, 435-449. [CrossRef]

22. Jain, S.; George, G.; Maltarich, M. Academics or entrepreneurs? Investigating role identity modification of university scientists involved in commercialization activity. Res. Policy 2009, 38, 922-935. [CrossRef]

23. O'kane, C.; Mangematin, V.; Geoghegan, W.; Fitzgerald, C. University technology transfer offices: The search for identity to build legitimacy. Res. Policy 2015, 44, 421-437. [CrossRef]

24. Bozeman, B.; Dietz, J.S.; Gaughan, M. Scientific and technical human capital: An alternative model for research evaluation. Int. J. Technol. Manag. 2001, 22, 716-740. [CrossRef]

25. Johnson, D.W.; Johnson, R.T. New developments in social interdependence theory. Genet. Soc. Gen. Psychol. Monogr. 2005, 131, 285-358. [CrossRef]

26. Tjosvold, D.; Chen, N.Y.; Huang, X.; Xu, D. Developing cooperative teams to support individual performance and well-being in a call center in China. Group Decis. Negot. 2014, 23, 325-348. [CrossRef] 
27. West, M.A.; Hirst, G. Cooperation and teamwork for innovation. In International Handbook of Organizational Teamwork and Cooperative Working; John Wiley and Sons Ltd.: Chichester, UK, 2003; pp. 297-319.

28. De Dreu, C.K. Cooperative outcome interdependence, task reflexivity, and team effectiveness: A motivated information processing perspective. J. Appl. Psychol. 2007, 92, 628-638. [CrossRef] [PubMed]

29. Deutsch, M. An experimental study of the effects of co-operation and competition upon group process. Hum. Relat. 1949, 2, 199-231. [CrossRef]

30. Tjosvold, D.; Andrews, I.R.; Struthers, J.T. Leadership influence: Goal interdependence and power. J. Soc. Psychol. 1992, 132, 39-50. [CrossRef]

31. Siegel, D.S.; Waldman, D.A.; Atwater, L.E.; Link, A.N. Toward a model of the effective transfer of scientific knowledge from academicians to practitioners: Qualitative evidence from the commercialization of university technologies. J. Eng. Technol. Manag. 2004, 21, 115-142. [CrossRef]

32. Goldfarb, B.; Henrekson, M. Bottom-up versus top-down policies towards the commercialization of university intellectual property. Res. Policy 2003, 32, 639-658. [CrossRef]

33. Raven, B.H.; Eachus, H.T. Cooperation and competition in means-interdependent triads. J. Abnorm. Soc. Psychol. 1963, 67, 307-316. [CrossRef]

34. Crombag, H.F. Cooperation and competition in means-interdependent triads: A replication. J. Personal. Soc. Psychol. 1966, 4, 692-695. [CrossRef]

35. Yim, D.S.; Kim, W.D. The evolutionary responses of Korean government research institutes in a changing national innovation system. Sci. Technol. Soc. 2005, 10, 31-55. [CrossRef]

36. Kwon, K.-S. Evolution of Universities and Government Policy: The case of South Korea. Asian J. Innov. Policy 2015, 4. [CrossRef]

37. Jung, J.; Mah, J.S. R\&D policies of Korea and their implications for developing countries. Sci. Technol. Soc. 2013, 18, 165-188.

38. Sabatier, P.A. Top-down and bottom-up approaches to implementation research: A critical analysis and suggested synthesis. J. Public Policy 1986, 6, 21-48. [CrossRef]

39. Sandholtz, K.W. Making standards stick: A theory of coupled vs. decoupled compliance. Organ. Stud. 2012, 33, 655-679. [CrossRef]

40. Fried, A.; Gey, R.; Pretorius, A.; Günther, L. Decoupling from standards-Process management and technical innovation in software development organisations. Int. J. Innov. Manag. 2013, 17, 1350012. [CrossRef]

41. Andrews, R.; Boyne, G.A.; Walker, R.M. Dimensions of publicness and organizational performance: A review of the evidence. J. Public Adm. Res. Theory 2011, 21, i301-i319. [CrossRef]

42. Lipsky, M. Street-Level Bureaucracy: Dilemmas of the Individual in Public Services; Russell Sage Foundation: New York, NY, USA, 1980.

43. Rainey, H.G.; Bozeman, B. Comparing public and private organizations: Empirical research and the power of the a priori. J. Public Adm. Res. Theory 2000, 10, 447-470. [CrossRef]

44. DeShon, R.P.; Kozlowski, S.W.; Schmidt, A.M.; Milner, K.R.; Wiechmann, D. A multiple-goal, multilevel model of feedback effects on the regulation of individual and team performance. J. Appl. Psychol. 2004, 89, 1035-1056. [CrossRef] [PubMed]

45. Kleingeld, A.; van Mierlo, H.; Arends, L. The effect of goal setting on group performance: A meta-analysis. J. Appl. Psychol. 2011, 96, 1289-1304. [CrossRef] [PubMed]

46. Locke, E.A.; Latham, G.P. Building a practically useful theory of goal setting and task motivation: A 35-year odyssey. Am. Psychol. 2002, 57, 705-717. [CrossRef] [PubMed]

47. Slocum Jr, J.W.; Cron, W.L.; Brown, S.P. The effect of goal conflict on performance. J. Leadersh. Organ. Stud. 2002, 9, 77-89. [CrossRef]

48. Emmons, R.A.; King, L.A. Conflict among personal strivings: Immediate and long-term implications for psychological and physical well-being. J. Personal. Soc. Psychol. 1988, 54, 1040-1048. [CrossRef]

49. Rizzo, J.R.; House, R.J.; Lirtzman, S.I. Role conflict and ambiguity in complex organizations. Adm. Sci. Q. 1970, 15, 150-163. [CrossRef]

50. Rainey, H.G.; Backoff, R.W.; Levine, C.H. Comparing public and private organizations. Public Adm. Rev. 1976, 36, 233-244. [CrossRef]

51. DeMatteo, J.S.; Eby, L.T.; Sundstrom, E. Team-based rewards: Current empirical evidence. Res. Organ. Behav. 1998, 20, 141-183. 
52. Yilmaz, C.; Hunt, S.D. Salesperson cooperation: The influence of relational, task, organizational, and personal factors. J. Acad. Mark. Sci. 2001, 29, 335-357. [CrossRef]

53. Deutsch, M. Equity, equality, and need: What determines which value will be used as the basis of distributive justice? J. Soc. Issues 1975, 31, 137-149. [CrossRef]

54. Janssen, O. Job demands, perceptions of effort-reward fairness and innovative work behaviour. J. Occup. Organ. Psychol. 2000, 73, 287-302. [CrossRef]

55. Leventhal, G.S. The distribution of rewards and resources in groups and organizations. Adv. Exp. Soc. Psychol. 1976, 9, 91-131.

56. Tjosvold, D. Cooperative and competitive goal approach to conflict: Accomplishments and challenges. Appl. Psychol. 1998, 47, 285-313. [CrossRef]

57. Tjosvold, D. The dynamics of interdependence in organizations. Hum. Relat. 1986, 39, 517-540. [CrossRef]

58. Tauer, J.M.; Harackiewicz, J.M. The effects of cooperation and competition on intrinsic motivation and performance. J. Personal. Soc. Psychol. 2004, 86, 849-861. [CrossRef]

59. Wageman, R. Interdependence and group effectiveness. Adm. Sci. Q. 1995, 40, 145-180. [CrossRef]

60. Deci, E.; Ryan, R.M. Intrinsic Motivation and Self-Determination in Human Behavior; Springer Science \& Business Media: New York, NY, USA, 1985.

61. Rahim, M.A.; Magner, N.R. Confirmatory factor analysis of the styles of handling interpersonal conflict: First-order factor model and its invariance across groups. J. Appl. Psychol. 1995, 80, 122-132. [CrossRef] [PubMed]

62. Rainey, H.G. Public agencies and private firms: Incentive structures, goals, and individual roles. Adm. Soc. 1983, 15, 207-242. [CrossRef]

63. Olson, M. The Logic of Collective Action; Harvard University Press: Cambridge, MA, USA, 1965.

64. Stanne, M.B.; Johnson, D.W.; Johnson, R.T. Does competition enhance or inhibit motor performance: A meta-analysis. Psychol. Bull. 1999, 125, 133-154. [CrossRef]

65. Saavedra, R.; Earley, P.C.; Van Dyne, L. Complex interdependence in task-performing groups. J. Appl. Psychol. 1993, 78, 61-72. [CrossRef]

66. Hogg, M.A.; Turner, J.C. Interpersonal attraction, social identification and psychological group formation. Eur. J. Soc. Psychol. 1985, 15, 51-66. [CrossRef]

67. Carron, A.V.; Widmeyer, W.N.; Brawley, L.R. The development of an instrument to assess cohesion in sport teams: The Group Environment Questionnaire. J. Sport Psychol. 1985, 7, 244-266. [CrossRef]

68. Tyler, T.R.; Blader, S.L. Identity and cooperative behavior in groups. Group Process. Intergroup Relat. 2001, 4, 207-226. [CrossRef]

69. Wageman, R.; Hackman, J.R.; Lehman, E. Team diagnostic survey: Development of an instrument. J. Appl. Behav. Sci. 2005, 41, 373-398. [CrossRef]

70. Hair, J.F.; Ringle, C.M.; Sarstedt, M. PLS-SEM: Indeed a silver bullet. J. Mark. Theory Pract. 2011, 19, $139-152$. [CrossRef]

71. Chin, W.W. The partial least squares approach to structural equation modeling. Mod. Methods Bus. Res. 1998, 295, 295-336.

72. Ringle, C.M.; Wende, S.; Becker, J.-M. SmartPLS 3; SmartPLS: Hamburg, Germany, 2015.

73. Hair, J.F.J.; Hult, G.T.M.; Ringle, C.M.; Sarstedt, M. A Primer on Partial Least Squares Structural Equation Modeling (PLS-SEM); Sage Publications, Inc.: Los Angeles, CA, USA, 2014.

74. Chung, K.H.; Lee, H.C.; Yi, H.-C.; Jung, K.H.; Jung, K.H.; Chŏng, K.-H. Korean Management: Global Strategy and Cultural Transformation; Walter de Gruyter: Berlin, Germany, 1997; Volume 81.

75. Tajfel, H.; Billig, M.G.; Bundy, R.P.; Flament, C. Social categorization and intergroup behaviour. Eur. J. Soc. Psychol. 1971, 1, 149-178. [CrossRef]

76. Turner, J.C.; Brown, R.J.; Tajfel, H. Social comparison and group interest in ingroup favouritism. Eur. J. Soc. Psychol. 1979, 9, 187-204. [CrossRef]

77. Hur, T.-K. Somehow Korean: Adolescent Psychology of Korean People; Joongang Books: Seoul, Korea, 2015. (In Korean)

78. Kim, H. Healing a Wary, Self-Cultivating Society through Education; Korea Development Institute: Seoul, Korea, 2018.

79. Kwon, S.-Y. The Relational Psychology of Korean People; Salim: Paju, Korea, 2007. (In Korean) 
80. Choung, J.-Y.; Hwang, H.-R.; Choi, J.K. Post catch-up system transition failure: The case of ICT technology development in Korea. Asian J. Technol. Innov. 2016, 24, 78-102. [CrossRef]

81. Magoshi, E.; Chang, E. Diversity management and the effects on employees' organizational commitment: Evidence from Japan and Korea. J. World Bus. 2009, 44, 31-40. [CrossRef]

82. Tjosvold, D.; Hui, C.; Law, K. The leadership relationship in Hong Kong: Power, interdependence, and controversy. In Progress in Asian Social Psychology; Leung, K., Ed.; Wiley: Singapore, 1997.

(C) 2019 by the authors. Licensee MDPI, Basel, Switzerland. This article is an open access article distributed under the terms and conditions of the Creative Commons Attribution (CC BY) license (http://creativecommons.org/licenses/by/4.0/). 